\title{
Survival of Listeria monocytogenes in Raw Milk
}

\author{
*May A. Al-Allaf \\ **Amera M. Al-Rawi \\ *Abdul Muhsin S. Al-Qazzaz \\ * Environmental and Pollution / Control Research Center / University of Mosul \\ ** Department of Biology / College of Science / University of Mosul \\ *E- mail: Mayallaf2@yahoo.com
}

(Received 24/9/2013; Accepted 16/12/2013)

\begin{abstract}
This study was conducted on different raw milk samples (cow, buffalo, sheep, goat) and pasteurized "Nada" milk was used as a control sample after confirming that it is free from any microbial contamination. Mesophilic aerobic bacteria (microbiota) was enumerated in all raw milk samples. Different concentrations of Listeria monocytogenes were inoculated at different dilutions of raw milk to detect the survival of this bacterium with the presence of microbiota in milk. The results showed the ability of Listeria monocytogenes to survive in raw milk samples with low levels of microbiota while it can not grow in the samples with high levels of microbiota and this survival differs with different origins of raw milk samples under study.
\end{abstract}

Keywords : Autochthonous microbiota, Listeria monocytogenes, Raw milk.

\section{Lقاءجرثومة Listeria monocytogenes في الحليب الخلم}

\begin{abstract}
المالغص
لجريت هذه الدرلسة عله عينت حليب خلم مختلفة (بقر، جلموس، غف، ماءز) ولستخدم حليب ندى المب ستر بوص فها

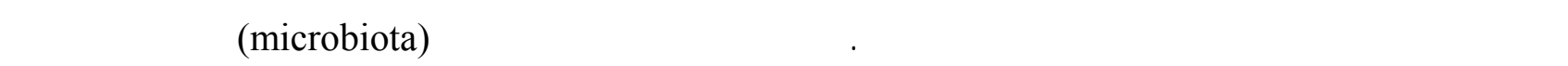
في الحليب الخلم بأنواعه. لقحت عينات الحليب بترلكيز مختافة من جرثومة Listeria monocytogenes لدرلسة مدى مقاومة

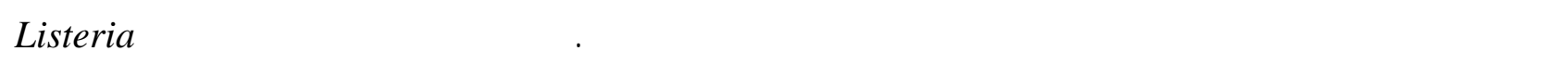

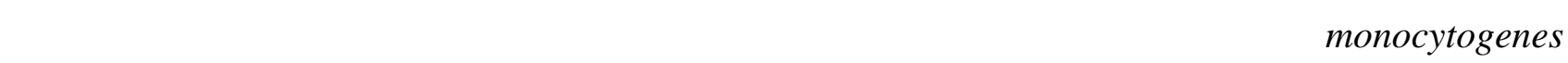

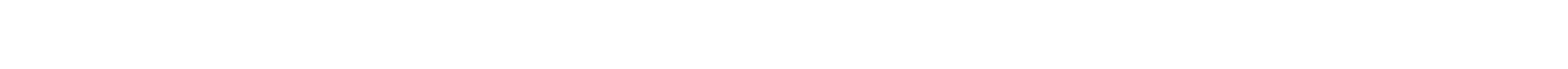
الحليب الخلم قيد الدرلسة.
\end{abstract}

\section{INTRODUCTION}

Listeria monocytogenes is an important pathogenic bacteria in medical and veterinary medicine that has an issue of global concern (Kalorey et al., 2008). It has an increased presence in milk and other food products (Jay et al., 2005). This bacteria can enter the host body and cause many hygienic problems as a serious opportunistic pathogens for both human and animals (Aygun and Pehlivanlar, 2006), it may cause a high mortality $20-30 \%$ associated with a mild illness (called listeriosis) that most prevalent in the elderly, pregnant women, AIDS patient and other immunecompromised patients. (Kells and Gilmour, 2004).

Listeria is a gram positive rods, facultative anaerobic, non-spore forming bacteria that lives in extreme and sever environments. This bacteria can survive in low temperature and it has a wide range of temperature for growth $(0-45)^{\circ} \mathrm{c}$, and it can grow over a wide range of $\mathrm{pH}$ values (4.3-9.1) (HPA, 2009; Thevenot et al., 2005). 
L. monocytogenes frequently contaminate food products of animal origin meat, milk especially those of poultry and eggs. (McCarron and Heaney, 2004).

Milk is a complete and enrichment food that contains protein, minerals and vitamins, that are necessary for the human body at different periods of growth and due to its high content of wet and natural acidity it is considered a good nutrient suitable for the growth of microorganisms, including pathogenic bacteria that may be transferred to human by using contaminated milk (Kasalica, 2000; Huth et al., 2006).

L. monocytogenes was isolated from raw milk of ruminants as a result of animal infection or contamination during collection and processing under poor hygienic conditions, machines, workers hands or clothes (Arques et al., 2005). Pasteurization can not protect milk from pathogenic bacteria, so it can survive during manufacture and storage due to inadequate pasteurization or postprocess contamination (Gameiro et al., 2007).

In view of the significance of $L$. monocytogenes economically and hygienically, the study aimed to detect the survival of this bacterium in raw milk samples of different origins after the determination of the levels of microbiota in these samples.

\section{MATERIALS AND METHODS}

\section{Bacterial strains}

Cultures of L. monocytogenes were obtained from Bacterial Strains Bank Unit in Biology Department/ College of Science /Mosul University.

\section{Raw milk samples}

The raw milk samples were collected from College of Agriculture/Mosul University, it includes (Cow, Buffalo, Sheep, Goat). The samples were transported immediately in a sterile containers under cooled condition to the bacteriological laboratory to perform the tests (Benson, 2012).

\section{Control milk samples}

Nada milk (Al-Othman Company/ King Saudi Arabia), was used as a control sample after examining it to insure the efficiency of its pasteurization. Then Nada milk was used to dilute the raw milk samples as follows:

A : $100 \mathrm{ml}$ raw milk

B : $10 \mathrm{ml}$ raw milk $\mathrm{A}+90 \mathrm{ml}$ Nada milk to obtain $10^{-1}$ dilution

$\mathrm{C}: 10 \mathrm{ml}$ from $\mathrm{B}+90 \mathrm{ml}$ Nada milk to obtain $10^{-2}$ dilution

D : $100 \mathrm{ml}$ Nada milk (control)

\section{Preparation of $L$. monocytogenes suspension}

Tryptic Soy Agar with $0.6 \%$ Yeast Extract (TSA-YE) was prepared as mentioned in the manufacture company information (Himedia). L. monocytogenes was inoculated on this medium and incubated for $24 \mathrm{hrs}$ at $37{ }^{\circ} \mathrm{C}$, isolated colonies were transferred to tryptic soy broth with $0.6 \%$ yeast extract and incubated for $18 \mathrm{hrs}$ at $37^{\circ} \mathrm{C}$. Viable L. monocytogenes count was performed using TSA-YE medium. Serial dilutions were done using normal saline, Serial dilutions were done from the stock solution to prepare $10^{-1}, 10^{-2}$ and $10^{-3}$ to obtain different pathogen concentrations to be tested ( Nero et al., 2009).

\section{Enumeration of mesophilic aerobes (microbiota) in raw milk samples}

$\mathrm{A}, \mathrm{B}$ and $\mathrm{C}$ raw milk samples were submitted to serial dilutions in normal saline. The dilutions of $10^{-5}, 10^{-6}$ were cultured on nutrient agar medium and incubated for $48 \mathrm{hrs}$ at $37^{\circ} \mathrm{C}$ to enumerate the mesophilic aerobic bacteria.

\section{Raw milk and control samples treatment with pathogen}

$\mathrm{A}, \mathrm{B}, \mathrm{C}$ and $\mathrm{D}$ were subdivided into four equal divisions, each one of these were inoculated with four different concentrations of $L$. monocytogenes including the original sample, $10^{-1}, 10^{-2}$ and $10^{-3}$. 


\section{Detection of $\mathbf{L}$. monocytogenes in different concentrations of different milk samples}

After inoculating the different concentrations of the bacteria in A, B, C and D milk samples, one $\mathrm{ml}$ of each of them was transferred to $5 \mathrm{ml}$ of TSB-YE and incubated for $48 \mathrm{hrs}$ at $37^{\circ} \mathrm{C}$. Then the cultures were transferred to TSA-YE media to perform morphological and biochemical tests according to (Nester et al., 2004 ; Mims et al., 2006), the results were recorded as positive or negative for growth.

\section{RESULTS AND DISCUSSION}

The viable count of $L$. monocytogenes in the stock solution was $36 \times 10^{6}(7.56 \log 10)$ and the numbers in $10^{-1}, 10^{-2}$ and $10^{-3}$ were $3.2 \times 10^{6}(6.51 \log 10), 1.1 \times 10^{6}(6.04 \log 10)$, and $0.6 \times 10^{6}$ (5.7 $\log 10)$ respectively.

The results showed that Nada milk samples were free from any microbial contamination which assure the efficiency of pasteurization.

The numbers of mesophilic aerobes in raw milk samples (autochthonous microbiota) were listed in (Table 1).

Table 1: Number of mesophilic aerobes microbiota in raw milk samples

\begin{tabular}{|c|c|c|c|}
\hline Milk origin & A (Raw) & B $\left(10^{-1}\right)$ & $C\left(10^{-2}\right)$ \\
\hline Cow & 32 & 21 & 7 \\
\hline Buffalo & 39 & 29 & 21 \\
\hline SWheep & 21 & 11 & 4 \\
\hline Goat & 27 & 16 & 7 \\
\hline
\end{tabular}

The numbers $\times 10^{6}$

The results showed that all raw milk samples were contaminated with different types of bacteria as shown in (Table 1) as autochthonous microbiota.

Buffalos milk samples were more contaminated type than the others: cow, sheep and goat milk samples. This may due to the differences in the chemical constituents of the different milk origin as well as to the physiological and genetical differences between the animals (Adesiyun et al., 2007).

Also the buffalo milk contains a high fat ratio (8\%) as phospholipids as well as it contains phospholipases that enhance the growth of many types of bacteria, while sheep and goat milk contains a high level of fatty acids such as capric, caproic, caprylic and butyric which inhibit the microbial growth (Robinson et al., 2000). Many studies referred that the differences in the microbiota in different animals were due to the nature of their environments, breeding and hygienic care especially types of food as well as the contaminated water (Quinn et al., 2006 ; Radostits et al., 2007).

In our study the results also showed that $L$. monocytogenes was recovered in all Nada milk samples regardless of the inoculum concentration of this pathogen. In addition the recovery of $L$. monocytogenes occurred in all raw milk samples with different variation depending on the concentration of the pathogen inoculums and the levels of microbiota (Figs 1-4). 


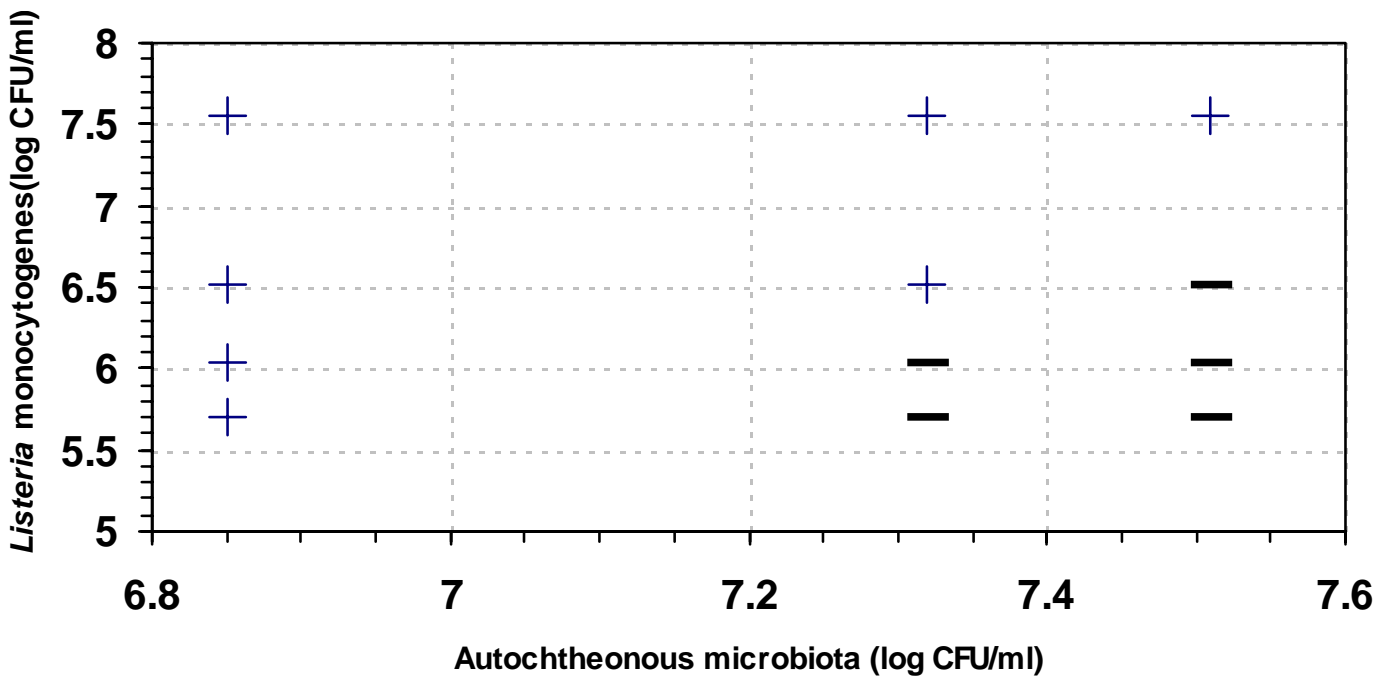

Fig. 1: Recovery of $L$. monocytogenes in cow milk (+ ability to survive and - inability to survive)

The recovery of L. monocytogenes from cow milk occurred with all treatments that presented concentrations of $7.5 \log \mathrm{CFU} / \mathrm{ml}$ of L. monocytogenes. For the treatment inoculated with $6 \log$ $\mathrm{CFU} / \mathrm{ml}$ and less of $L$. monocytogenes, the recovery occurred when the autochthonous microbiota contamination was less than $7.2 \log \mathrm{CFU} / \mathrm{ml}$, while the recovery was possible at concentration of $7.32 \log \mathrm{CFU} / \mathrm{ml}$ microbiota with $6.5 \log \mathrm{CFU} / \mathrm{ml}$ of L. monocytogenes Fig. (1).

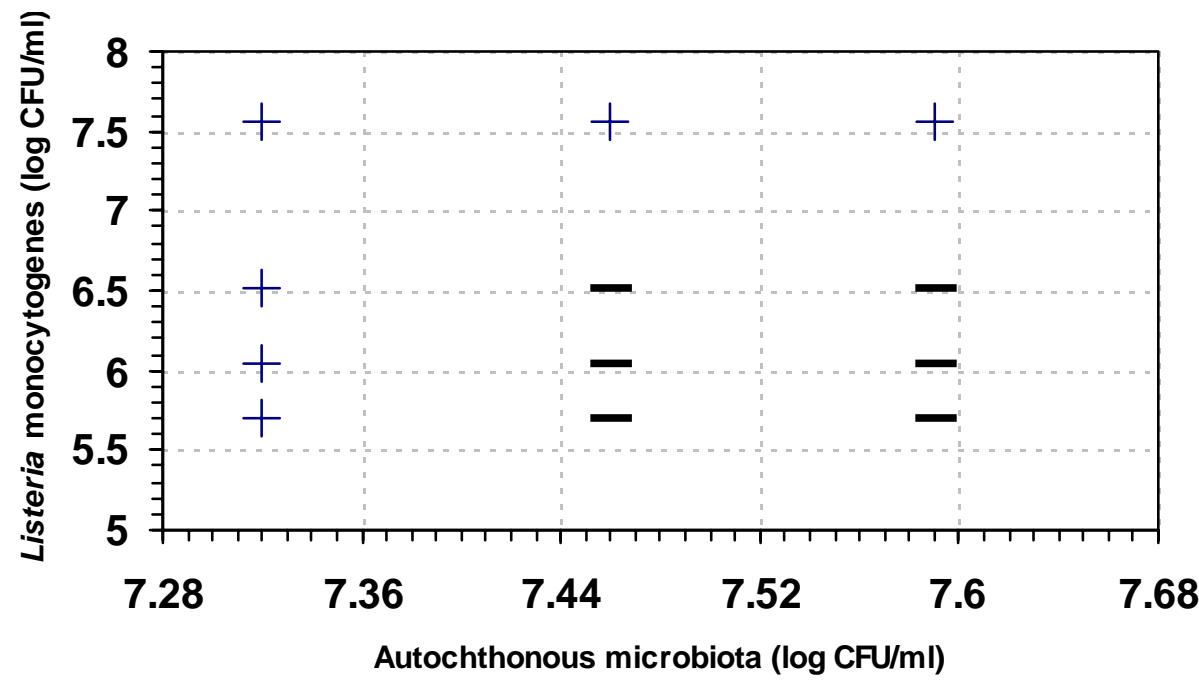

Fig. 2: Recovery of L. monocytogenes in buffalo milk (+ ability to survive and - inability to survive)

For buffalo milk, the recovery of $L$. monocytogenes obtained at all treatments that presented concentrations higher than $7.5 \mathrm{log} \mathrm{CFU} / \mathrm{ml}$ of the pathogen, but when the autochthonous microbiota contamination was higher than $7.32 \mathrm{log} \mathrm{CFU} / \mathrm{ml}$ the recovery did not occur in the treatment inoculated with $6.5 \log \mathrm{CFU} / \mathrm{ml}$ of L. monocytogenes or less Fig. (2). 


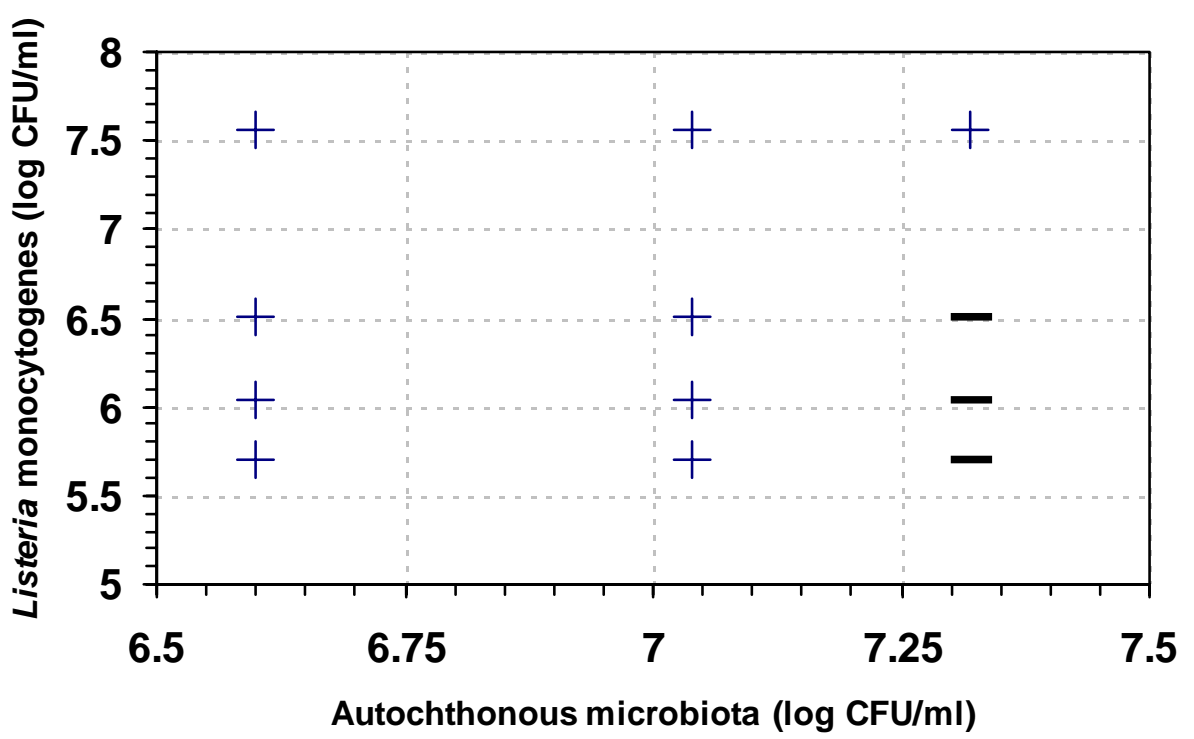

Fig. 3: Recovery of L. monocytogenes in sheep milk (+ ability to survive and - inability to survive)

For sheep milk, the recovery of $L$. monocytogenes obtained in all treatment that presented a concentration higher than $7.5 \log \mathrm{CFU} / \mathrm{ml}$, additionally the recovery occurred in all treatment of $L$. monocytogenes with microbiota contamination level lower than $7.25 \log \mathrm{CFU} / \mathrm{ml}$, while the recovery did not occur when the autochthonous microbiota contamination was higher than $7.25 \log$ CFU/ml Fig. (3).

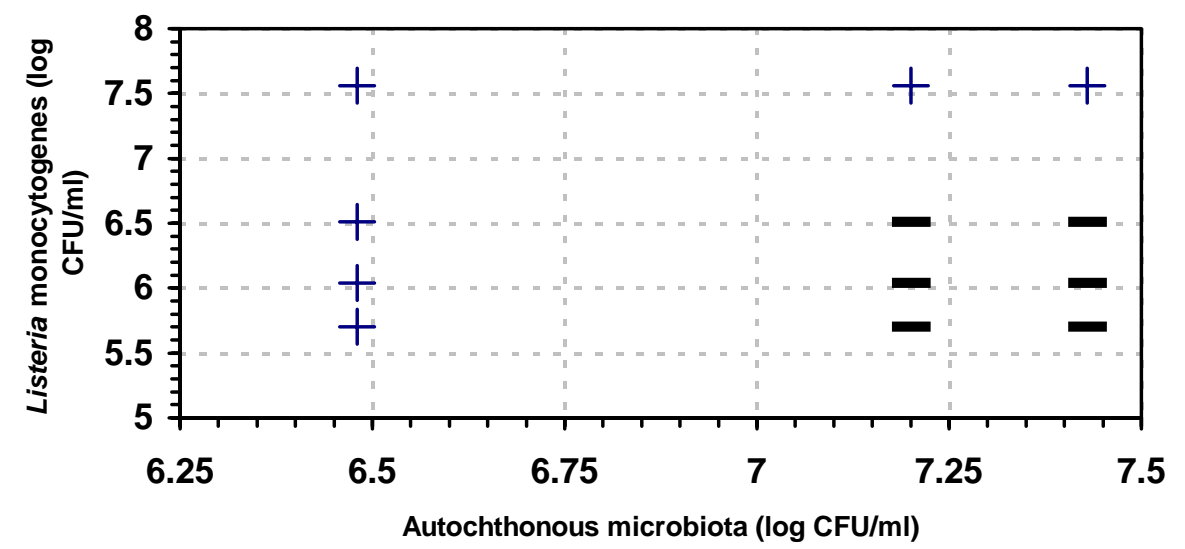

Fig. 4: Recovery of L. monocytogenes in goat milk (+ ability to survive and - inability to survive)

For goat milk, the recovery of L. monocytogenes obtained at all treatments that presented a concentration higher than $7.5 \log \mathrm{CFU} / \mathrm{ml}$ of the pathogen and at a concentration lower than $6.5 \log$ $\mathrm{CFU} / \mathrm{ml}$ autochthonous microbiota for all inoculums levels of $L$. monocytogenes, but the pathogen was not recovered in other treatments.

Generally, a higher concentration of L. monocytogenes with a high contamination level of autochthonous microbiota lead to a great recovery of $L$. monocytogenes, while the recovery of this bacterium did not occur when the pathogen concentrations were low, but it may be possible only when the microbiota of raw milk was high. When $L$. monocytogenes present at level of $36 \times 10^{6}$ the recovery occurred in all treatments with low or high contamination levels of microbiota in all raw 
milk samples and their dilutions, while the recovery did not occur if L. monocytogenes present at level less than that, and the autochthonous microbiota $18-29 \times 10^{6}$ and the recovery occurred when the contamination was less than $18 \times 10^{6}$.

The recovery of $L$. monocytogenes in raw milk samples may due to the composition of the milk (Robinson et al ., 2000).

Autochthonous microbiota play a very important role which represents the main interfering factor such as different types of metabolites produced by microbiota in the milk as an unfavorable conditions that can inhibit the bacterial growth or survival by competition (Besse, 2002). The multiplication of autochthonous microbiota in the initial phase of L. monocytogenes growth may cause, decrease in $\mathrm{pH}$ with a consequent inhibition of the multiplication and detection of this pathogen (Carr et al., 2002). Moreover, many antimicrobial substances in the raw milk that contribute to this interference such as lactoferrin, whey proteins, casein fragments bacteriophages and lacto-peroxides system, all these substances associated with specific storage and processing conditions that can induce stress on $L$. monocytogenes impairing their development and recovery (Hadson et al., 2005).

In this study the negative results of detection of L. monocytogenes in raw milk samples may due to our proceeding, culture media and methodologies which were used in detection of this bacteria and this agreed with (Suh and Knabel, 2001). Alternative methods must be used such as molecular techniques and different selective media such as Half-Fraser broth to enhance the growth of this pathogen during the isolation and recovery procedures from raw milk samples (Wher and Frank, 2004).

\section{REFERENCES}

Adesiyun, A.; Stoute, S.; David, B. (2007). Pre-processed bovine milk quality in Trinidad : prevalence and characteristics of bacterial pathogens and occurrence of antimicrobial residues in milk from collection centres. J. Food Control. 18(4), 312-320.

Arques, L.; Rodriguez, E.; Gaya, P.; Nunez, M. (2005). Effect of combinations of high pressure treatment and bacteriocin producing Lactic acid bacteria on the survival of Listeria monocytogenes in raw milk cheese. J. Int. Diary 15(6-9), 893-900.

Aygun, O.; Pehivanlar, S. (2006). Listeria sp. In the raw milk and dairy products in Antakya, Turky. J. Food Control. 17(8), 676-679.

Benson, J. (2012). "Microbiological Application". 8th edn., Laboratory Manual in General Microbiology. The McGraw-Hill companies Inc. 17 p.

Besse, G. (2002). Influence of various environmental parameters and of detection procedures on the recovery of stressed L. monocytogenes: a review. J. Food Microboil. 19(2-3),221-34.

Carr, F.; Chill, D.; Maida, N. (2002). The lactic acid bacteria: a literature survey. Crit Rev Microbiol. 28(4), 281-370.

Collee, J.; Fraser, A.; Marmion, B.; Simmons, A. (2006). "Mackie and McCartney Practical Medical Microbiology". 14th edn., Churchill Livingstone, New York.

Gameiro, N.; Ferreiro-Dias, S.; Ferreiro, M. (2007). Evolution of Listeria monocytogenes populations during the ripening of naturally contaminated raw ewes milk cheese. J. Food Control. 18(10), 1258-1262.

Hadson, A.; Billinngton C.; Greening, G. (2005). Bacteriophages as biocontrol agent in Food. $J$ Food Prot. 68(2),426-437.

Health Protection Agency(HPA). (2009). "Detection and Enumeration of Listeria monocytogenes and other Listeria Species". National Public Health Service for Wales. Standard Method, Ref. No. 19, pp. 1-18.

Huth, P.; DiRienzo, D.; Miller, G. (2006). Major scientific advances with dairy foods in nutrition and health. J. Dairy Sci., 89(4),1207-1221. 
Jay, M.; Lossner, M.; Golden, D. (2005). "Modern Food Microbiology". 7th edn. Gaithersburg: ASPEN Publishers. New York, pp.700-720.

klalorey, R.; Warke, S.; Kurkure, N.; Barbuddhe, S. (2008). Listeria species in bovine raw milk : A large survey of Central India. J. Food Control, 19(2),109-112.

Kasalica, A. (2000). Yersinia enterocolitica in milk. J. Sci. Agric. Researc. 61(1-20), 183-194.

Kells, J.; Gilmour, A. (2004). Incidence of Listeria monocytogenes in two milk processing environments and assessment of Listeria monocytogenes blood agar for isolation . J. Int. Food Microbial. 91(2), 167-174.

McCarron, D.; Heaney, R. (2004). Estimated healthcare savings associated with adequate dairy food intake. J. Am Hypertens. 17(1), 88-97.

Mims, C.; Dockrell, M.; Goering, R.; Roitt, I.; Zucherman, M. (2006). " Medical Microbiology". 3rd edn. El Sevier Mosby British Library. pp. 592-593.

Nero, L.; Mattos, M.; Aguiar, M.; Barros, F. (2009). Interference of raw milk autochthonous microbiota on the performance of conventional methodologies for Listeria monocytogenes and Salmonella spp. J. Microbio. Research 164(1), 529-535 www.elsevier.de/micres

Nester, E.; Anderson, D.; Roberts, C.; Pearsall, N. (2004). "Microbiology". A human perspective. McGraw Hill Companies. New York. pp. 668-670.

Quinn, P.; Carter, M.; Markey, B. (2004). "Clinical Veterinary Microbiology". 2nd edn., Mosby Int., USA, pp. 95-96.

Radostits, O.; Henderson, J.; Gay, C. (2007). "Veterinary Medicine". A Textbook of the Diseases of Cattle, Sheep, Pigs, Goats and Horses . 11th edn. Bailliere, Tindall Comp. UK, pp. 45-48.

Robinson, R.; Batt, C.; Patel, D. (2000). "Encyclopedia of Food Microbiology". San Diago, pp.120125.

Suh, H.; Knabel, S. (2001). Comparison of different enrichment broth and background flora for detection of heat-injured Listeria monocytogenes in whole milk. J. Food Prot. 64(1), 30-36.

Thevenot, D.; Delignette-Muller, L.; Christieans, S. (2005). Fate of Listeria monocytogenes in experimentally contaminated French sausages. J. Int. Food Microbiol. 101(2), 189-200.

Wher, H.; Frank, J. (2004). "Standard Methods for the Examination of Dairy Products". 17th edn. Washington: American Public Health Association, pp. 100-115. 